\title{
Familial incidence of bifid and double ureters
}

\author{
J. D. ATWELL, P. L. COOK, C. J. HOWELL, I. HYDE, and B. C. PARKER \\ From the Wessex Regional Centre for Paediatric Surgery, the Children's Hospital, Southampton
}

Atwell, J. D., Cook, P. L., Howell, C. J., Hyde, I., and Parker, B. C. (1974). Archives of Disease in Childhood, 49, 390. Familial incidence of bifid and double ureters. The incidence of a duplex urinary tract was determined in the parents and sibs of 30 index patients with either unilateral or bilateral bifid or double ureters. Our results support the hypothesis that a duplex urinary tract is inherited by an autosomal dominant gene of variable penetrance. Routine screening by limited intravenous pyelography of sibs of index patients is recommended in order to detect a duplex urinary tract before the onset of complications.

The finding of double ureters in members of the same family is a rare occurrence, and by 1966 only 7 such families had been reported (Girsh and Karpinski, 1956; Burkland, 1958). Later, after the investigation of families of children with a duplex urinary tract, it was suggested that the inheritance of this anomaly was by an autosomal dominant gene (Whitaker and Danks, 1966). Duplications of the ureter in adults are often symptomless, but in children the risk of infection is increased twentyfold (Campbell and Harrison, 1970). This may be secondary to vesicoureteric reflux or obstruction, and as recurrent urinary infections in children may lead to the insidious onset of chronic pyelonephritis, it is important to detect a duplex urinary tract before the onset of these complications. These facts, together with one of us (J.D.A.) being involved in the treatment of a mother and 3 daughters all with duplex urinary tracts, led to our present investigation. Our aim was to determine the incidence of a duplex collecting system in the parents and sibs of infants and children with double or bifid ureters and to decide whether routine screening of the family was justifiable.

\section{Clinical series and method}

Duplications of the ureter were either complete (double ureter) or incomplete (bifid ureter). A bifid renal pelvis was considered as a variant of an incomplete duplex collecting system. The first-degree relatives of 30 index patients with either double or bifid ureters were investigated by limited intravenous pyelography with a control and 20-minute films.

Received 2 November 1973.

\section{Results}

There were 11 male and 19 female index patients of whom 17 had double ureters (complete duplex) and $13 \mathrm{had}$ bifid ureters (incomplete duplex). 7 of the index patients had a bilateral duplex system.

Limited pyelography was performed in all the sibs of the index patients and in 56 of their 60 parents. One difficulty experienced in interpreting results was the relation between a bifid pelvicalyceal system and bifid and double ureters. If a bifid pelvicalyceal system is included as a variant of a duplex system, 20 families ( $66 \%$ ) had affected first-degree relatives. When relatives with a bifid pelvicalyceal system were excluded, 9 families (30\%) had firstdegree relatives with complete or incomplete duplication of one or both ureters. Some families had more than one affected relative.

A more detailed analysis of our results is seen in Table I which shows the radiological findings in the 29 fathers, 27 mothers, and 45 sibs of our 30 index patients. Table II shows the findings in the sibs

TABLE I

Radiological findings in parents and sibs of 30 index patients

\begin{tabular}{|c|c|c|}
\hline \multirow{2}{*}{$\begin{array}{l}\text { Relationship to } \\
\text { index patient }\end{array}$} & \multicolumn{2}{|c|}{ Radiological findings } \\
\hline & $\begin{array}{l}\text { Bifid pelvicalyceal } \\
\text { system }\end{array}$ & $\begin{array}{l}\text { Double and/or } \\
\text { bifid ureters }\end{array}$ \\
\hline $\begin{array}{l}29 \text { fathers } \\
27 \text { mothers } \\
45 \text { sibs }\end{array}$ & $\begin{array}{l}8 \\
5 \\
8\end{array}$ & $\begin{array}{l}1 \\
3 \\
7\end{array}$ \\
\hline Total of 101 relatives & 21 & 11 \\
\hline
\end{tabular}


TABLE II

Radiological findings in sibs of 11 male and 19 female index patients

\begin{tabular}{c|c|c}
\hline & Radiological findings \\
\cline { 2 - 3 } & $\begin{array}{c}\text { Bifid pelvicalyceal } \\
\text { system }\end{array}$ & $\begin{array}{c}\text { Double and/or } \\
\text { bifid ureters }\end{array}$ \\
\hline $\begin{array}{c}13 \text { sibs of } 11 \text { male } \\
\text { index patients } \\
32 \text { sibs of } 19 \text { female } \\
\text { index patients }\end{array}$ & 2 & 1 \\
\hline
\end{tabular}

when related to the sex of the index patient. Full details of all 30 families investigated are shown in the Appendix.

To determine the frequency of a bifid renal pelvis in children, we reviewed 364 consecutive intravenous pyelograms in children attending our Radiological Department in 1971. We found 15 children with a bifid pelvicalyceal pattern, an incidence of $4.1 \%$. We excluded patients who were members of the families of our duplex index patients and intravenous pyelograms on neonates with spina bifida; patients were also excluded if there was inadequate concentration, distortion, or obstruction so that the pelvicalyceal detail was unclear.

\section{Discussion}

Nearly $10 \%$ of all human beings are born with a congenital anomaly of the urogenital system (Burkland, 1958) and duplication of the upper urinary tract is one of the commoner anomalies and occurs in about 1 in 160 individuals (Campbell and Harrison, 1970; Nation, 1944). Our finding of a duplex system (excluding a bifid renal pelvis) in 11 of 101 relatives or 32 of 101 relatives (including a bifid renal pelvis) contrasts markedly with the predicted incidence in the population. In patients with anorectal and spina bifida anomalies there is a higher incidence of renal tract anomalies (Scott, Swenson, and Fisher, 1960; Roberts, 1961). Despite this, we found only 2 duplex urinary tracts in 35 patients with a congenital anorectal anomaly and 3 in 153 patients with myeloceles or meningomyeloceles. Thus, the high incidence of a duplex system in parents and sibs of the index patients adds further support to the hypothesis that the congenital malformation has a genetic basis.

In our series, excluding index patients, 101 out of 105 possible had an intravenous pyelogram and a duplex system was found in 32 parents or sibs. This finding is suggestive of an autosomal dominant type of inheritance. Further support is provided by the findings in 13 families with one or the other parent affected, where 18 of 32 sibs were affected. However, in 14 families without either parent affected, 19 of 36 sibs had a duplex urinary tract. One explanation (Whitaker and Danks, 1966) is that the inheritance is by a dominant gene which fails to become manifest in some patients, i.e. is of low penetrance.

A duplex urinary tract is prone to infection, either from obstruction associated with an ectopic ureter or from vesicoureteric reflux. In double ureters this is usually to the ipsilateral lower collecting system, though reflux is often seen to the contralateral kidney even if it is single.

In our series it was interesting to find vesicoureteric reflux occurring in the sibs of our duplex index patients (Appendix, families 12, 17, and 18) and in some of these patients the presence of pyelonephritis had previously been unsuspected (Fig.). As such recurrent infection can lead to

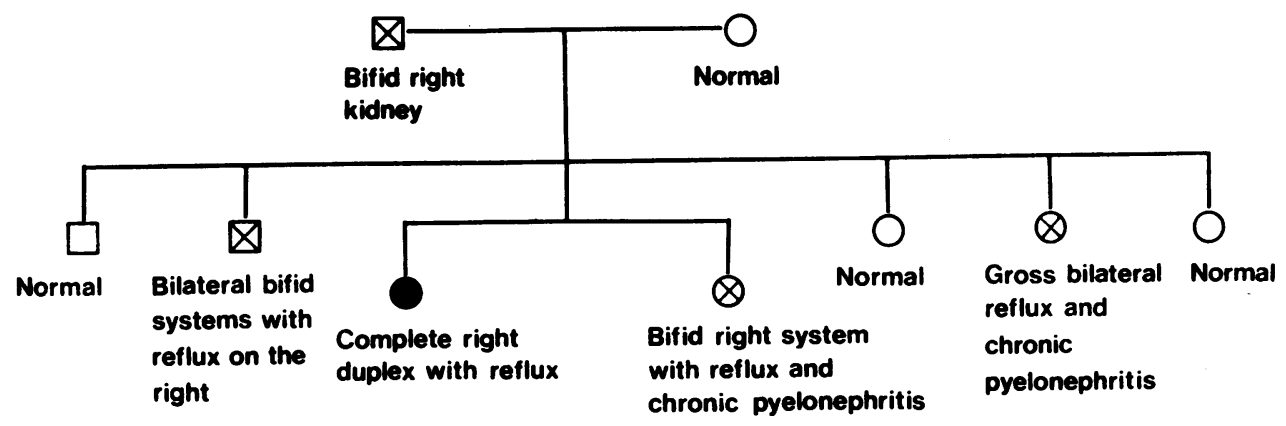

FIG.-Family no. 12 with identical twins and familial reflux. 
chronic pyelonephritis with the later development of hypertension and renal failure, in our opinion it seems justifiable to try and prevent such a sequence of events. Screening of first-degree relatives has been suggested following certain case reports (Girsh and Karpinski, 1956; Burkland, 1958), though other authors felt it was unjustifiable (Whitaker and Danks, 1966) as they found no case of occult disease in symptom-free relatives. This has not been our experience, as several children were found with previously undiagnosed pyelonephritis and reflux, also one of the mothers has since died from hypertension after infection in a duplex kidney despite a recent nephrectomy.

The correlation between familial duplication and familial vesicoureteric reflux has not yet been determined but is under further investigation. If the position of the ureteric orifice is genetically determined it is possible that lateral displacement is present in sibs of patients with a duplex system, thus predisposing to the development of reflux. We consider that these findings justify the use of limited intravenous pyelography in the sibs of index patients.
We thank the radiographers of the Southampton Children's Hospital for their help during this survey, in particular Mrs. Elizabeth Nunn; and also thank Drs. Elspeth Williamson and Cedric Carter for invaluable advice in the preparation of this paper.

\section{RBFBRENCES}

Burkland, C. E. (1958). The significance of genetic and environmental factors in urogenital disease. fournal of Urology, 79, 532.

Campbell, M. F., and Harrison, J. H. (1970). Urology, 3rd ed., Vol. 2, pp. 1488, 1800 . Saunders, Philadelphia.

Girsh, L. S., and Karpinski, F. E., Jr. (1956). Urinary tract malformations, their familial occurrence, with special reference to double ureter, double pelvis and double kidney. New England fournal of Medicine, 254, 854.

Nation, E. F. (1944). Duplication of the kidney and ureter. A statistical study of 230 new cases. Fournal of Urology, 51, 456.

Roberts, J. B. M. (1961). Congenital anomalies of the urinary tract and their association with spina bifida. British fournal of Urology, 33, 309.

Scott, J. E. S., Swenson, O., and Fisher, J. H. (1960). Some comments on the surgical treatment of imperforate anus. American fournal of Surgery, 99, 137.

Whitaker, J., and Danks, D. M. (1966). A study of the inheritance of duplication of the kidneys and ureters. Fournal of Urology, 95, 176.

Correspondence to Mr. J. D. Atwell, Wessex Regional Centre for Paediatric Surgery, Southampton Children's Hospital, Winchester Road, Southampton SO9 4WR.

Appendix

Details of patients and families

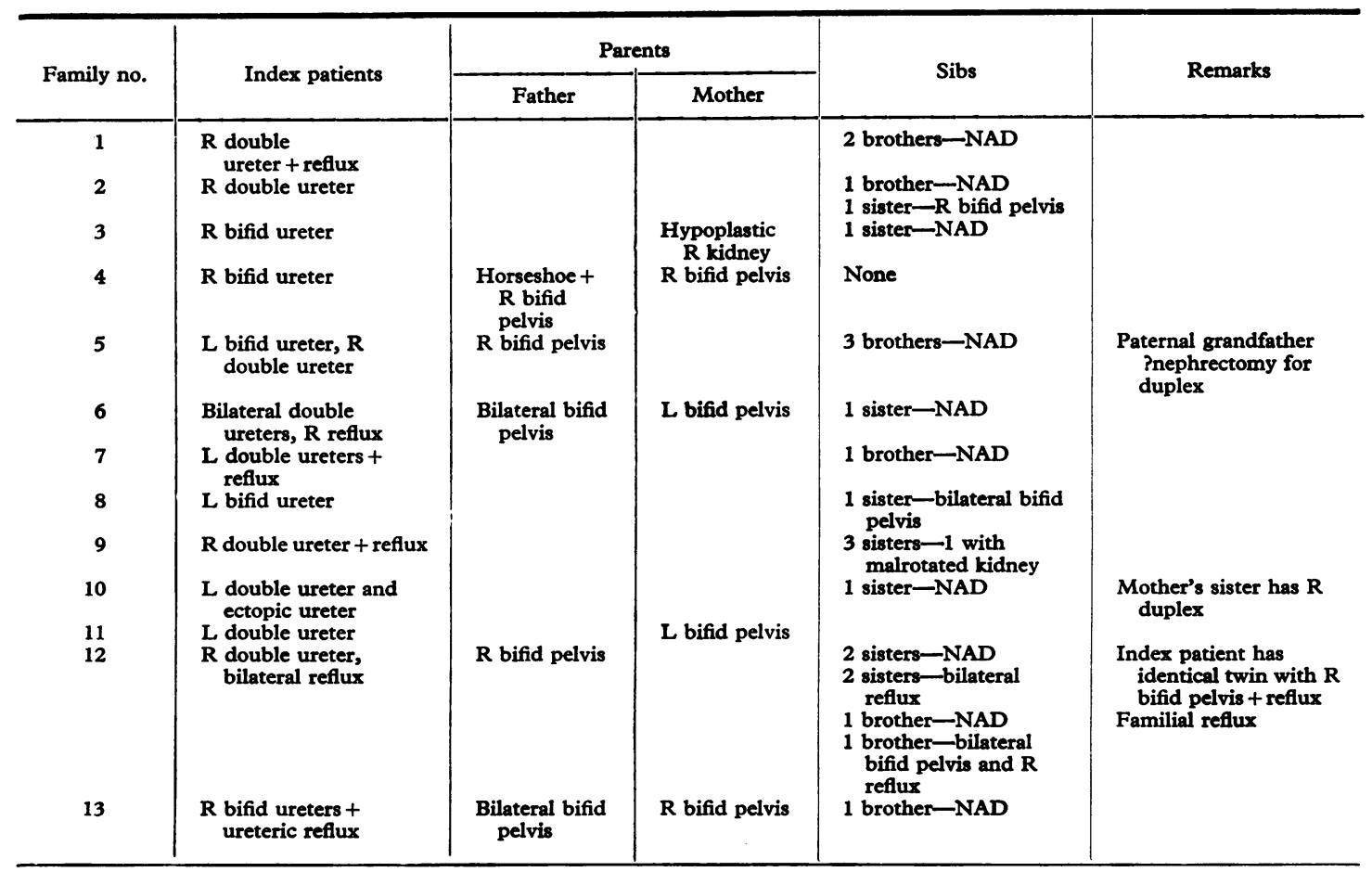


Appendix-continued

Details of patients and families

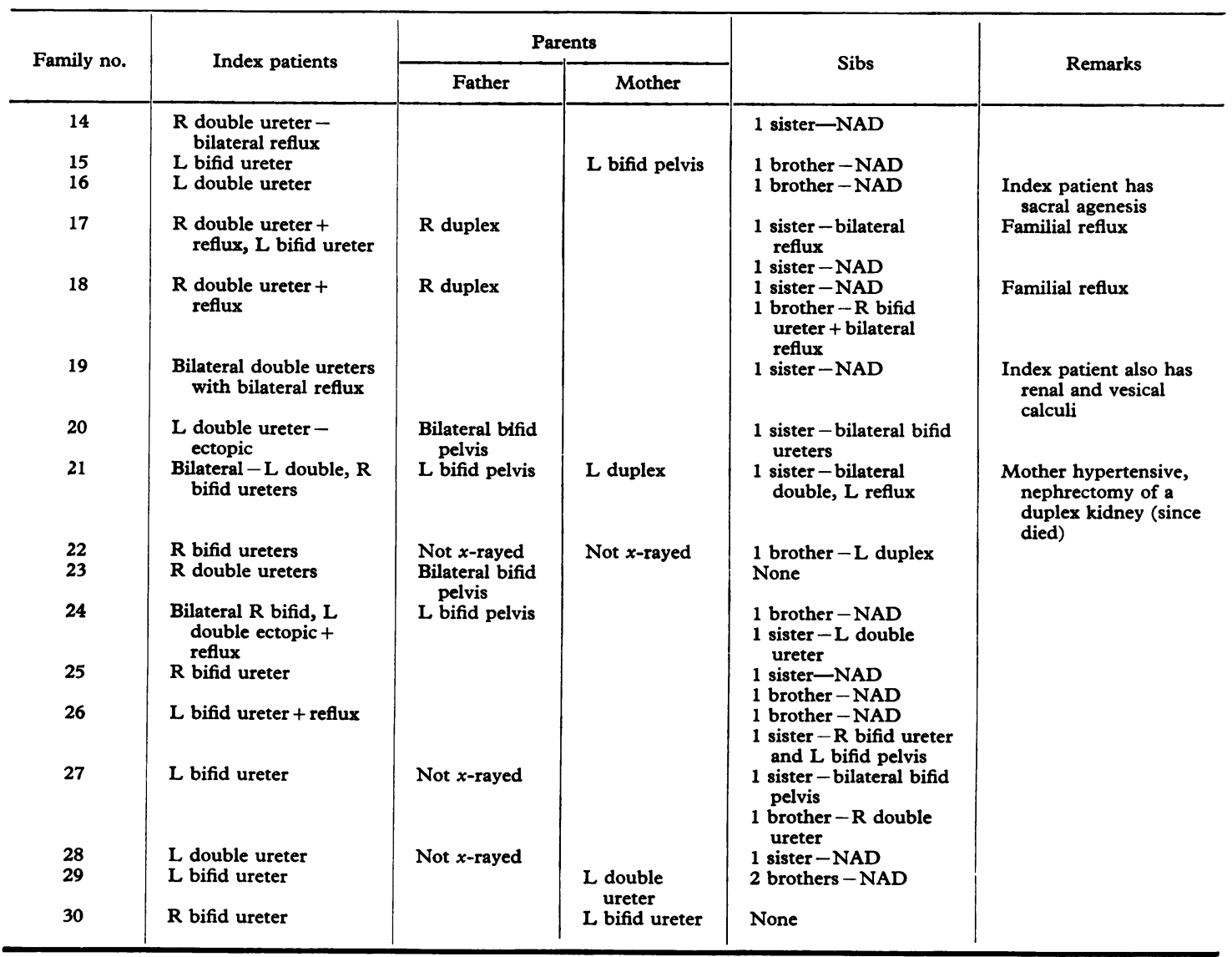

R, right; L, left; NAD, no abnormalities detected. 